\title{
Anti-inflammatory and anti-nociceptive effects of Zeyheria montana (Bignoniaceae) ethanol extract
}

\author{
LC Guenka, RC Gomes, VL Melo, CRR Kitanishi, PS Pereira, SC França, LB Couto, RO Beleboni/ ${ }^{+}$
}

Unidade de Biotecnologia, Universidade de Ribeirão Preto, Av. Costabile Romano 2201, 14096-380 Ribeirão Preto, SP, Brasil

\begin{abstract}
In this work, the analgesic and anti-inflammatory activities of Zeyheria montana Mart. ethanol leaf extract were investigated at doses of 75, 150 and $300 \mathrm{mg} / \mathrm{kg}$ body weight. In the analgesic assay, against a chemical stimulus in mice, acetic acid-induced writhes were significantly inhibited by the extract at doses of $75 \mathrm{mg} / \mathrm{kg}(67.27 \%), 150 \mathrm{mg} /$ $\mathrm{kg}(49.38 \%)$ and $300 \mathrm{mg} / \mathrm{kg}(82.87 \%)$. Also, a vigorous decrease in hyperalgesia was observed when measured after $2 \mathrm{~h}$ and $6 \mathrm{~h}$ of lipopolysaccharide stimulation of rats for all doses of extract tested. Z. montana extract, at doses of 75 and $300 \mathrm{mg} / \mathrm{kg}$, caused very slight central analgesia in rats submitted to thermal stimulus, particularly noticeable at 30 min following treatment. The anti-inflammatory activity of Z. montana extract on carrageenan-induced oedema in rats was evaluated. The oedema development, measured at 180 min following carrageenan intraplantar injection, was significantly reduced by all tested doses: $75 \mathrm{mg} / \mathrm{kg}(33.30 \%), 150 \mathrm{mg} / \mathrm{kg}(45.80 \%)$ and $300 \mathrm{mg} / \mathrm{kg}(75.00 \%)$. The $L D_{50}$ value was greater than $2000 \mathrm{mg} / \mathrm{kg}$. These results demonstrated that the ethanol extract from $\mathrm{Z}$. montana leaf possesses anti-nociceptive and anti-inflammatory activities, which could be of relevance for the pharmacological control of pain and inflammatory processes.
\end{abstract}

Key words: anti-inflammatory - anti-nociceptive - Zeyheria montana

Non-steroidal anti-inflammatory drugs (NSAIDs) are among the most important drugs used in the reduction of pain and inflammation. Their efficacy has been confirmed by a wide number of experimental and clinical studies (Kean \& Buchanan 2005, Zochling et al. 2006, Ong et al. 2007). Despite their efficacy, the use of NSAIDs induces serious adverse effects when administrated chronically, with the gastrointestinal tract being the most affected system (Ofman et al. 2002). For this purpose, an increasing number of studies are being carried out in search of new therapeutics from medicinal plants, especially those with proclaimed popular use as anti-inflammatory and analgesic agents (Gupta et al. 2006).

Zeyheria montana Mart. (Bignoniaceae) [syn. Zeyheria digitalis (Vell). Hoehne], commonly known as "bolsa de pastor", is a plant species native to the Brazilian "cerrado". Z. montana leaf and root extracts are conventionally used in Brazilian folk medicine for the treatment of ulcers, skin tumours and inflammatory diseases (Jacome et al. 1999, Bertoni et al. 2007). Phytochemical analyses of $Z$. montana leaf extract showed the presence of terpenoids and flavonoids, while root and stem extracts are particularly rich in lapachol (Almeida et al. 1990, Machado et al. 2006). Indeed, the amount of lapachol produced by $Z$. montana is about 19 times higher than in Tabebuia avallenedae, a plant species also from the Bignoniaceae family and traditionally known as the

+ Corresponding author: rbeleboni@unaerp.br

Received 22 May 2008

Accepted 28 November 2008 main source of this compound (Almeida et al. 1990, Jacome et al. 1999). Previous results have validated the popular use of $T$. avallenedae in the treatment of inflammatory and infectious disease, as well as an inhibitor of tumour growth, which has been mainly linked to the action of lapachol (Goel et al. 1987, Almeida et al. 1990, Favaro et al. 1990, Miranda et al. 2001). Moreover, the terpenoid ursolic acid has been isolated from $Z$. montana and is associated with $Z$. montana's anti-tumour activities (Varanda et al. 1992).

Therefore, based on ethnopharmacological information, the aim of this work was to evaluate the analgesic and anti-inflammatory effects of $Z$. montana ethanol leaf extract.

\section{MATERIAL AND METHODS}

Drugs - Acetic acid was purchased from Chemco, Campinas, SP, Brazil; Aspirin from Bayer, São Paulo, SP, Brazil; Carrageenan from Sigma, St. Louis, MO, USA; indomethacin $\left(\right.$ Indocid $^{\mathrm{R}}$ ) from Merck Sharp-Dolme, UK; and Tramadol, from Biosintética, São Paulo, SP, Brazil. Polyoxyethylene Sorbitan Monolaurate $\left(\right.$ Tween $^{\mathrm{R}}$ 20) was from USB (Cleveland, Ohio, USA) and solvents from Synth (São Paulo, SP, Brazil).

Animals - Pharmacological and toxicological experiments were carried out using Wistar albino male rats (150-250 g) or Swiss albino male mice (18-25 g) bred at the University of São Paulo (Ribeirão Preto, SP, Brazil) and at ANILAB Company (Paulínia, SP, Brazil), respectively. Animals were kept in cages under a $12 \mathrm{~h}$ light $/ 12 \mathrm{~h}$ dark cycle at $21 \pm 3^{\circ} \mathrm{C}$, with food and water ad libitum and acclimatised to the laboratory room for 2-3 $\mathrm{h}$ prior to pharmacological experiments, which were performed under sound-attenuated conditions and at a controlled temperature $\left(20-22^{\circ} \mathrm{C}\right)$. All experiments were performed 
following the guidelines of the Brazilian Society of Neurosciences and received the approval of the Ethical Committee at the Universidade de Ribeirão Preto (UNAERP) (protocol n. 102/08).

Plant collection and extraction procedure - Z. montana leaves were collected in Franca, São Paulo, Brazil, and identified at the Instituto de Botânica at University of Campinas (Campinas, SP, Brazil). A voucher specimen (803) is kept in the Herbarium of UNAERP. Dried and powdered leaves $(1 \mathrm{~kg})$ were macerated in $95 \%$ ethanol $(5.0 \mathrm{~L})$ for $24 \mathrm{~h}$ at $25^{\circ} \mathrm{C}$ and the filtrate was concentrated, lyophilised and resuspended in distilled water prior to use.

High pressure liquid chromatography (HPLC) profile of $Z$. montana leaf ethanol extract - In order to obtain the chromatographic profile of $Z$. montana leaf ethanol extract, HPLC analysis was performed on a Shimadzu LC10ADvp system equipped with a Supelco LC18 column (SupelcosilTM RP-18, $250 \times 4.6 \mathrm{~mm}$ id), coupled to a diode array detector, monitored at $210 \mathrm{~nm}$ to triterpenes and $280 \mathrm{~nm}$ to flavonoids. A two-solvent gradient system of water-acetic acid $0.1 \%$ (A) and methanol (B) was used. Ethanol extract $(5 \mathrm{mg} / \mathrm{mL})$ and triterpene standards (betulin, betulinic acid, oleanolic acid and ursolic acid) were eluted with $85 \%$ of $\mathrm{B}$, at $1.0 \mathrm{~mL} / \mathrm{min}$ under isocratic conditions. The gradient program for flavonoid analysis, using Zeyherin A and B as standards for comparison to the ethanol extract $(5 \mathrm{mg} / \mathrm{mL})$, consisted of three periods: (i) $0-20 \mathrm{~min}, 40-85 \% \mathrm{~B}$, (ii) $20-22 \mathrm{~min}, 85-40 \% \mathrm{~B}$ and (iii) $22-28 \mathrm{~min}, 40 \% \mathrm{~B}$, at a flow-rate of $1.0 \mathrm{~mL} / \mathrm{min}$. The identification of triterpenes and flavonoids in the ethanol extract was done by comparing their retention times and spectral data with those of standard compounds.

Anti-nociceptive activity: acetic acid-induced abdominal constrictions in mice - Z. montana leaf extract $(75,150$ or $300 \mathrm{mg} / \mathrm{kg}$, ip), aspirin $(100 \mathrm{mg} / \mathrm{kg}$, po) and saline (100 $\mu \mathrm{L}$, ip) was administrated $60 \mathrm{~min}$ prior to the ip injection of $100 \mu \mathrm{L}$ of $1 \%$ acetic acid in male Swiss mice that were divided into control $(n=7)$ and experimental groups $(n=$ 7). After a latency time of $5 \mathrm{~min}$, the number of writhing and stretching movements were counted over a period of $30 \mathrm{~min}$ and expressed as a percentage of analgesic activity according to the following equation: \% analgesic activity $=\mathrm{N}-\mathrm{N}^{1} / \mathrm{N} \times 100$, where $\mathrm{N}$ is the number of abdominal contractions of animals treated with saline and $\mathrm{N}^{1}$ is the number of abdominal contractions of animals treated with Z. montana extract or aspirin.

Anti-nociceptive activity: hyperalgesia test (Hargreaves) - Z. montana leaf extract $(75,150$ and $300 \mathrm{mg} /$ $\mathrm{kg}$, ip), aspirin $(100 \mathrm{mg} / \mathrm{kg}$, po) or saline $(100 \mu \mathrm{L}$, ip) was administered $60 \mathrm{~min}$ prior to the intraplantar injection of lipopolysaccharide (LPS) (250 ng/paw) in male Wistar rats that were divided into control $(\mathrm{n}=6)$ and experimental groups $(n=6)$. Briefly, the hyperalgesia was evaluated as previously described (Hargreaves et al. 1988, Costello \& Hargreaves 1989), where the hyperalgesia intensity was assessed by the variation in the time of animal reaction (index of hyperalgesia, $\mathrm{IH}$ ) following the equation: $\mathrm{IH}=(\mathrm{To} / \mathrm{Tn})-1$, with $\mathrm{To}$ and $\mathrm{Tn}$ being the basal time of animal reaction before LPS injection and the time values measured at $2 \mathrm{~h}$ and $6 \mathrm{~h}$ after the LPS stimulation, respectively.

Anti-nociceptive activity: nociceptive response induced by a thermal stimulus - Experiments were carried out following the method of Hargreaves et al. (1988) with modifications. Rats, distributed into control $(\mathrm{n}=9)$ and experimental $(n=9)$ groups, were individually placed in an acrylic box under a mobile infrared heating lamp at $55+1.0^{\circ} \mathrm{C}$ (Ugo Basile equipment, Varese, Italy). The basal time reaction, the time elapsed until the animal reacted (shaking and/or lifting its right hind-paw), was observed over a period of $60 \mathrm{~min}$ prior to treatments. Animals were injected with $Z$. montana leaf extract (75, 150 or $300 \mathrm{mg} / \mathrm{kg}$, ip), tramadol (100 mg/kg, ip) or saline $(100 \mu \mathrm{L}$, ip) $60 \mathrm{~min}$ prior to the thermal stimulus. The latency time for the animal response was recorded at 30 , 60, 120 and $180 \mathrm{~min}$.

Anti-inflammatory activity: inhibition of carrageenan-induced paw oedema - The anti-inflammatory effects of $Z$. montana extract were measured according to Winter et al. (1962). Right hind-paw volume of each animal in control $(n=7)$ or in experimental $(n=7)$ groups was measured prior to any treatments using a digital Plethysmometer 7140 (Ugo Basile, Verese, Italy). Z. montana extract $(75,150$ or $300 \mathrm{mg} / \mathrm{kg}$, ip), indomethacin $(10 \mathrm{mg} /$ $\mathrm{kg}$, ip) or saline $(100 \mu \mathrm{L}$, ip) was administered to animals $60 \mathrm{~min}$ before the injection of $50 \mu \mathrm{L}$ of an aqueous solution of carrageenan $(01 \%, w / v)$ into the subplantar region of right hind-paw. Moreover, paw volumes were measured after carrageenan injection at times of 30, 60, 120 and $180 \mathrm{~min}$. In this work, paw volume determinations were the average value of three repeated measures. Percentage of oedema development inhibition was expressed using the following equation: \% oedema development inhibition $=[(V \mathrm{t}-V 0)$ control $-(V \mathrm{t}-V 0)$ treated $] /$ $(V \mathrm{t}-V 0) \times 100$, where $V \mathrm{t}$ is the average paw volumes for each group and $V 0$ average paw volumes for each group prior to treatments, according to Lanhers et al. (1991).

Toxicological assays - Male Swiss mice, distributed into five groups of six animals each, were treated with Z. montana leaf extract $(125,250,500,1000$ or $2000 \mathrm{mg} /$ $\mathrm{kg}$, po) containing $2.5 \%$ Tween-20 (v/v). Controls received $0.1 \mathrm{~mL}$ of saline also containing $2.5 \%$ Tween-20 $(\mathrm{v} / \mathrm{v})(\mathrm{po})$. Signs of toxicity were recorded for $24 \mathrm{~h}$ and $\mathrm{LD}_{50}$ was calculated from the plotted data. Ulcerogenic effect of $Z$. montana leaf extract $(75,150$ or $300 \mathrm{mg} /$ $\mathrm{kg}$, po) was determined as described by Volterra et al. (1974), with modifications.

Statistical analyses - Statistical significance was determined by ANOVA following Student's $t$ test. Results were considered significant at $\mathrm{p}<0.05$.

\section{RESULTS AND DISCUSSION}

Since geographic distribution, environmental and plant physiological conditions may contribute to the great morphological and chemical diversity of plant species (Zoghbi et al. 1998), a chromatographic profile of $Z$. montana ethanol leaf extract, as compared to flavonoid 
and triterpene standards used as phytochemical markers, is provided in Figs 1 and 2. This information should be of relevance in the future to find the active compound(s) in the Z. montana extract.

As showed in Table I, Z.montana leaf extract caused a reduction in the number of acetic acid-induced abdominal constrictions at doses of $75 \mathrm{mg} / \mathrm{kg}(67.27 \%), 150 \mathrm{mg} /$ $\mathrm{kg}(49.38 \%)$ and $300 \mathrm{mg} / \mathrm{kg}(82.87 \%)$. A reduction in acetic acid-induced writhes $(64.83 \%)$ was also caused by a $100 \mathrm{mg} / \mathrm{kg}$ dose of aspirin, however, this effect was inferior to those obtained by extract doses of 75 and $300 \mathrm{mg} /$ $\mathrm{kg}$. Acid acetic-induced abdominal constrictions are a useful experimental tool in the testing of new analgesic drugs. The abdominal injection of acetic acid in mice has been attributed to the release of arachidonic acid via
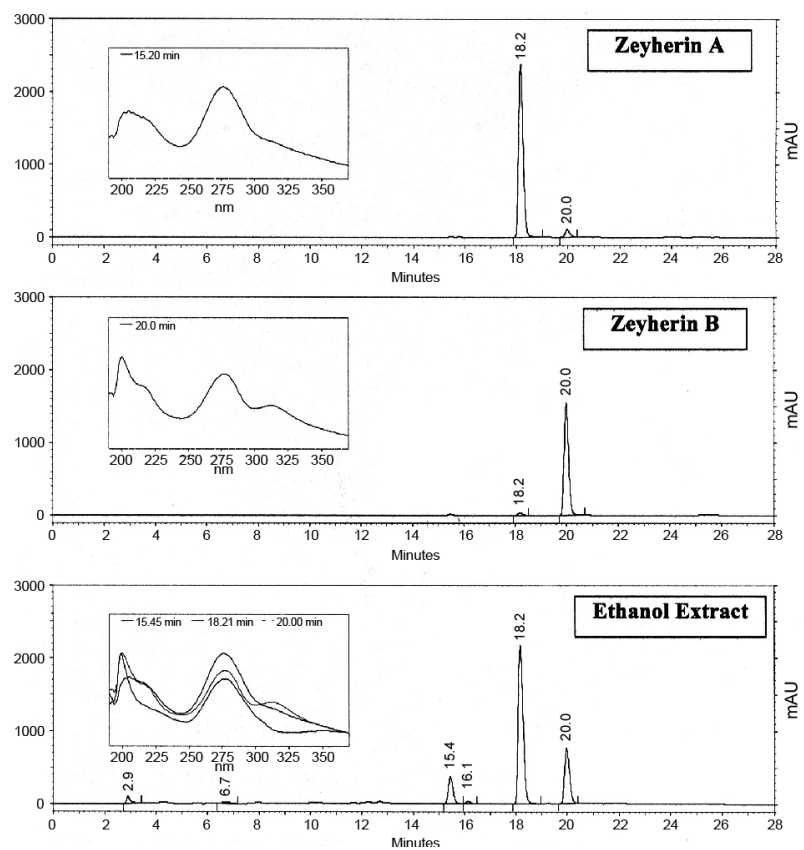

Fig. 1: chromatographic profile of the zeyherin A (18.1 min) and zeyherin B (19.9 min) and Zeyheria montana ethanol extracts at $280 \mathrm{~nm}$.
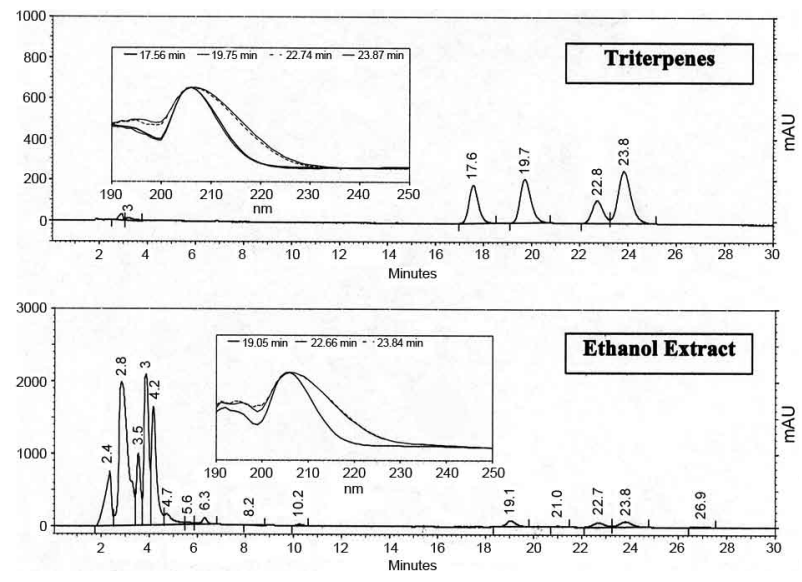

Fig. 2: chromatographic profile of the triterpene standards and Zeyheria montana ethanol extracts at $210 \mathrm{~nm}$. Betulin (17.5 min), betulinic acid (19.7 $\mathrm{min})$, oleanolic acid (22.7 $\mathrm{min})$ and ursolic acid $(23.8 \mathrm{~min})$. the cyclooxygenase enzyme. Also, it has been suggested that the inhibition of prostaglandin synthesis by this pathway is remarkably efficient as an anti-nociceptive mechanism in visceral pain (Franzotti et al. 2002). Since all tested doses of $Z$. montana leaf extract were able to inhibit the acetic acid-induced writhes, the peripheral analgesic activity exhibited by this extract may be related to the inhibition of prostaglandin production. Peripheral analgesic activity of $Z$. montana extract was also confirmed by the hyperalgesia test (Hargreaves) (Fig. 3). All evaluated doses were able to inhibit hyperalgesia to a similar extent as aspirin. At two and six hours after LPS stimulation, the degrees of hyperalgesia reduction were, respectively, $91.60 \%$ and $85.70 \%(75 \mathrm{mg} / \mathrm{kg}), 83.30 \%$ and $57.10 \%$ (150 mg/kg), 83.30\% and $85.70 \%$ (300 mg/kg).

Thermal stimuli are frequently used in the investigation of new opioid analgesic compounds and in differentiating non-narcotic analgesics from narcotic ones (Turner 1965, Plummer et al. 1996). Only a very slight central analgesic effect was observed in rats treated with $Z$. montana extract. The latency time for the animal writhing/ stretching response was discreetly increased by extract doses of 75 and $300 \mathrm{mg} / \mathrm{kg}, 30 \mathrm{~min}$ following treatment, while tramadol showed its greatest analgesic effect after 60 min (Table II). Thus, Z. montana leaf extract seems to have a very weak central analgesia effect, whereas it is clear that it has peripheral analgesic activity (Table I).

The carrageenan-induced rat paw oedema is prompted by an early event involving the release of high concentrations of histamine and serotonin (Vinegar et al. 1969). The late phase of the inflammatory process, after the first $60 \mathrm{~min}$ of oedema induction, is characterised by the presence of prostaglandins $\left(\mathrm{PGI}_{2}\right)$, bradykinin and maximal oedema volume (Di Rosa et al. 1971, Gilman 1985). At the doses and time duration assayed, Z. montana leaf extract significantly reduced oedema development after carrageenan injection (Fig. 4). The administration of $Z$. montana leaf extract before the injection of the flogistic agent, at doses of $75 \mathrm{mg} / \mathrm{kg}, 150 \mathrm{mg} / \mathrm{kg}$ and $300 \mathrm{mg} / \mathrm{kg}$,

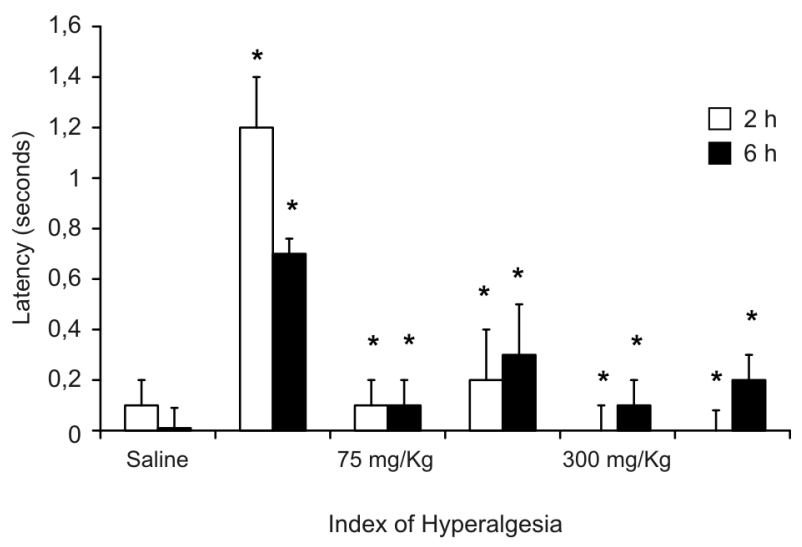

Fig. 3: results show the latency time for hind paw withdrawn at $2 \mathrm{~h} / 6 \mathrm{~h}$ after lipopolysaccharide (LPS) stimulation. Each bar is the mean \pm s.e.m. from six animals for group. Asterisk indicates: $p<0.01$ when compared to saline/LPS group (ANOVA following Student's $t$ test). Antinociceptive effect of Zeyheria montana leaf extract in hyperalgesia test (Hargreaves). 
prevented the development of oedema in $15.30 \%, 23.00 \%$ and $38.40 \%$ of animals, respectively, after $30 \mathrm{~min}$ and in $17.60 \%, 35.20 \%$ and $47.00 \%$, of animals, respectively, after $60 \mathrm{~min}$. After 120 and $180 \mathrm{~min}$, doses of $75 \mathrm{mg} / \mathrm{kg}$ (30.00\% and $33.30 \%$, respectively), $150 \mathrm{mg} / \mathrm{kg}(20.00 \%$ and $45.80 \%$, respectively) and $300 \mathrm{mg} / \mathrm{kg}(50.00 \%$ and $75.00 \%$, respectively) caused a more pronounced level of protection against oedema development. Indomethacin also exhibited effective anti-inflammatory activity, inhibiting the paw oedema development in $38.40 \%$, $47.00 \%, 65.00 \%$ and $70.80 \%$ of animals after $30,60,120$

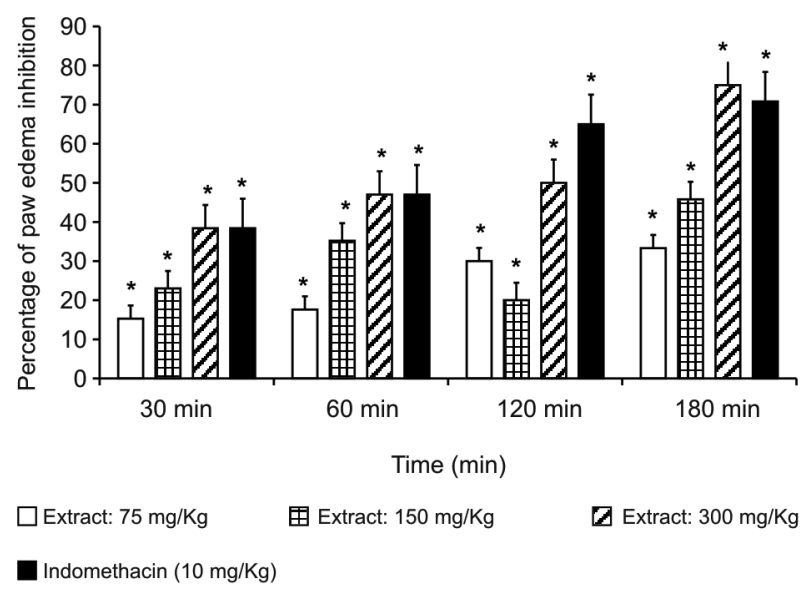

Fig. 4: anti-inflammatory effect of Zeyheria montana leaf extract in carrageenan-induced rat paw edema test. Results show the \% of paw edema inhibition. Asterisk indicates $(\mathrm{p}<0.05)$ when experimental group was compared to saline control group. and $180 \mathrm{~min}$, respectively. Since $Z$. montana leaf extract exhibited a marked anti-inflammatory effect during the early and late phases of oedema, it is possible that compounds present in this extract play a role in decreasing the histamine/serotonin release rate, as well as could act as bradykinin/prostaglandin synthesis inhibitors.

No signs of toxicity, such as diarrhoea, motor impairment, ataxia, hyperexcitability or alterations on respiratory frequency or piloerection, were noted in the control or experimental animals. Also, no gastric ulcerogenic effect was observed in controls or in animals treated with $Z$. montana extract $(75,150,300 \mathrm{mg} / \mathrm{kg}$, po), while an ulcerogenic index of $16.2 \pm 6.6$ was observed in animals treated with indomethacin $(48 \mathrm{mg} / \mathrm{kg}, \mathrm{po})$ (data not shown). The LD50 (at $24 \mathrm{~h}$ ) was greater than $2000 \mathrm{mg} /$ $\mathrm{kg}$, indicating the safety of $Z$. montana leaf extract.

Bertoni et al. (2003) reported the isolation of the flavones zeyherin a (8-hydroxi-5,6,7-trimethoxyflavone) and zeyherin b (6-hydroxi-5,6,7-trimethoxyflavone) from $Z$. montana leaf extract. Those substances share a high chemical similarity with a flavone from Zeyheria tuberculosa, described by Kutney and Hanssen (1971), which exhibits significant anti-herpes virus activity (Hayashi et al. 1997). In addition, the pentacyclic triterpenes betulinic acid, ursolic acid and oleanolic acid, with validated anti-inflammatory activity, were found in $Z$. montana leaves (Bertoni et al. 2007). Since an essential database on the chemical profile of $Z$. montana leaf extract is established, in which flavones and triterpenes are the major constituents, this information should be considered for future purification of analgesic and

TABLE I

Antinociceptive effect of Zeyheria montana leaf extract on acetic acid-induced abdominal constrictions in mice

\begin{tabular}{lcccc}
\hline & Dose & Number of \\
Treatments & animals & 7 & $\begin{array}{c}\text { Number of } \\
\text { abdominal constrictions } \\
(30 \text { mim) }\end{array}$ & $\begin{array}{c}\text { Abdominal constrictions } \\
\text { percent inhibition } \\
(\%)\end{array}$ \\
\hline Acetic acid control & 00 & 7 & $93.42 \pm 6.47$ & 0.00 \\
Extract & 75 & 7 & $30.57 \pm 10.90^{a}$ & 67.27 \\
Extract & 150 & 7 & $47.28 \pm 12.88^{a}$ & 49.38 \\
Extract & 300 & 7 & $16.00 \pm 5.16^{a}$ & 82.87 \\
Aspirin & 100 & $32.85 \pm 6.69^{a}$ & 64.83 \\
\hline
\end{tabular}

$a$ : experimental groups compared to saline control group $(\mathrm{p}<0.05)$. Values are means \pm SEM.

TABLE II

Antinociceptive effect of Zeyheria montana leaf extract against a thermal stimulus

\begin{tabular}{lcccccc}
\hline Treatments & $\begin{array}{c}\text { Dose } \\
\mathrm{mg} / \mathrm{kg}\end{array}$ & $0 \mathrm{~h}$ & $30 \mathrm{~min}$ & $60 \mathrm{~min}$ & $90 \mathrm{~min}$ & $120 \mathrm{~min}$ \\
\hline Control & 0 & $13.33 \pm 0.90$ & $14.86 \pm 2.46$ & $18.06 \pm 2.90$ & $17.88 \pm 3.41$ & $15.86 \pm 2.88$ \\
Extract & 75 & $16.90 \pm 1.08$ & $20.13 \pm 2.25^{a}$ & $18.31 \pm 2.20$ & $19.91 \pm 2.12$ & $19.18 \pm 3.14$ \\
Extract & 150 & $13.75 \pm 1.25$ & $20.18 \pm 2.77$ & $19.45 \pm 3.96$ & $17.73 \pm 2.26$ & $18.78 \pm 2.96$ \\
Extract & 300 & $18.39 \pm 1.45$ & $21.90 \pm 2.94^{a}$ & $17.23 \pm 2.94$ & $18.30 \pm 2.12$ & $18.26 \pm 2.74$ \\
Tramadol & 100 & $15.70 \pm 2.06$ & $24.90 \pm 2.87^{a}$ & $26.15 \pm 2.70$ & $24.41 \pm 3.35^{a}$ & $21.50 \pm 2.31$ \\
\hline
\end{tabular}

$a$ : experimental groups compared to saline control group $(\mathrm{p}<0.05)$. Values are means \pm SEM. 
anti-inflammatory active compounds from this natural source. Our results indicate that $Z$. montana leaf extract has both effective peripheral analgesic activity and pronounced anti-inflammatory activity, even when compared to known drugs, such as aspirin and indomethacin. Furthermore, the extract exhibited a low $\mathrm{LD}_{50}$ value. Finally, the obtained results point out the potential of $Z$. montana leaf extract for the pharmacological control of pain and inflammatory processes.

\section{REFERENCES}

Almeida ER, Silva-Filho AAA, Santos ER, Lopes C 1990. Antiinflamatory action of lapachol. J Ethnopharmacol 29: 239-241.

Bertoni BW 2003. Propagation genetic and chemical variability of Zeyheria montana Mart, $\mathrm{PhD}$ Thesis, Universidade Estadual Paulista, Jaboticabal, São Paulo, 165 pp.

Bertoni BW, Astolfi Filho S, Martins ER, Damião Filho CF, França SC, Pereira AMS, Telles MPC, Diniz Filho JF 2007. Genetic variability in natural populations of Zeyheria montana Mart. from the Brazilian cerrado. Sci Agric (Piracicaba, Braz) 64: 409-415.

Costello AH, Hargreaves KM 1989. Suppression of carrageenan induced hyperalgesia, hyperthermia and edema by a bradykinin antagonist. Eur J Pharmacol 171: 259-263.

Di Rosa M, Papadimitrion JP, Willoughby DA 1971. Study of the mediators of the acute inflammatory response induced in rats in different sites by carrageenan and tupentine. J Pathol 104: 15-29.

Favaro OCN, Oliveira MM, Rossini MAA, Kamukura CR, Pinto AV, Pinto MCRF 1990. Selection by means of KB cells of substances and extracts potentially active in cancer chemotherapy. An Acad Bras Cienc 62: 217-224.

Franzotti EM, Santos CV, Rodrigues HM, Mourão RH, Andrade MR, Antoniolli AR 2002. Anti-inflammatory, analgesic and acute toxicity of Sida cadifolia L. J Ethnopharmacol 72: 273-278.

Gilman AG 1985. The pharmacological basic of therapeutics. In BA Flower, S Moncada, JR Vane (eds.), Analgesic antipyretic and anti-inflammatory agents: drugs employed in the treatment of gout. 7th ed., Macmillan Publishing, New York, p. 674-715.

Goel RK, Pahaak NK, Biwas M, Pandey VB, Sanyal AK 1987. Effect on lapachol, a naphquinone isolated from Tectona grandis on experimental pectic ulcer and gastric secretion. J Pharm Pharmacol 39: 138-140.

Gupta M, Mazumder UK, Gomathi P, Thamil Selvan V 2006. Antiinflammatory evaluation of leaves of Plumeria acuminate. BMC Complement Altern Med 6: 36.

Hargreaves K, Dubner R, Brown F, Flores C, Joris J 1988. A new and sensitive method for measuring thermal nociception in cutaneous hyperalgesia. Pain 32: 77-88.

Hayashi K, Hayashi T, Otsuka H, Takeda Y 1997. Antiviral activity of 5,6,7-trimethoxyflavone and its potentiation of the antiherpes activity of acyclovir. J Antimicrob Chemother 39: 821-824.
Jacome LRP, Oliveira AB, Raslan D, Muller A, Wagner H 1999. Analysis of naphtoquimones in Zeyheria montana crude extracts (bolsa-de-pastor). Quim Nova 22: 175-177.

Kean WF, Buchanan WW 2005. The use of NSAIDs in rheumatic disorders 2005: a global perspective. Inflammopharmacology 13: 343-370.

Kutney JP, Hanssen HWH 1971. 5,6,7-trimethoxyflavone and 5,6,7,8-tetramethoxyflavone from Zeyheria tuberculosa. Phytochemistry 10: 3298-3302.

Lanhers MC, Fleurentin J, Dorfman P, Mortier F, Pelt JM 1991. Analgesic, antipyretic and anti-inflammatory properties of Euphorbia hirta. Planta Med 57: 225-231.

Machado SR, Gregorio EA, Guimaraes E 2006. Ovary peltate trichomes of Zeyheria montana (Bignoniaceae): developmental ultra structure and secretion in relation to function. Ann Bot 97: 357-369.

Miranda FGG, Vilar JG, Alves IAN, Cavalcanti SCH, Antoniolli AN 2001. Antinociceptive and antiedematogenic properties and acute toxicity of Tabebuia avellanedae Lor. ex Griseb. inner bark aqueous extract. BMC Pharmacol 1: 1471-2210.

Ofman JJ, MacLean CH, Straus WL, Morton SC, Berger ML, Roth EA, Shekelle P 2002. A metaanalysis of severe upper gastrointestinal complications of nonsteroidal antiinflammatory drugs. $J$ Rheumatol 29: 804-812.

Ong CKS, Lirk P, Tan CH, Seymour RA 2007. An evidence-based update on nonsteroidal anti-inflammatory drugs. Clin Med Res 5: 19-34.

Plummer JL, Cmielewski PL, Gourly GK, Owen H, Cousins M 1996. Assessment of antinociceptive drug effects in the presence of impaired motor performance. J Pharmacol Methods 26: 79-84.

Turner RA 1965. Screening Methods in Pharmacology, Vol. 1, Academic Press, New York, 106 pp.

Varanda EM, Zunga GE, Salatino A, Roque NF, Corcuera LJ 1992. Effect of ursolic acid from epicuticular waxes of Jacaranda decurrens on Schizaphis graminum. J Nat Prod 55: 800-803.

Vinegar R, Schreiber W, Hugo R 1969. Biphasic development of carrageenan-edema in rats. J Pharmacol Exp Ther 166: 96-103.

Volterra G, Pisanti N, Meli A 1974. Factors influencing the development of indomethacin-induced intestinal ulcers in the rat. Proc Soc Exp Biol Med 146: 146-152.

Winter CA, Risley EA, Nuss GW 1962. Carrageenan-induced edema in hind paw of the rat as an assay for anti-inflammatory drugs. Proc Soc Exp Biol Med 11: 544-547.

Zochling J, Van der Heijde D, Dougados M, Braun J 2006. Current evidence for the management of ankylosing spondylitis: a systematic literature review for the ASAS/EULAR management recommendations in ankylosing spondylitis. Ann Rheum Dis 65: 423-432.

Zoghbi MGB, Andrade EHA, Santos AS, Silva MHL, Maia JGS 1998. Essential oils of Lippia alba (Mill.) N. E. Br growing wild in the Brazilian Amazon. Flavour Frag J 13: 47-48. 